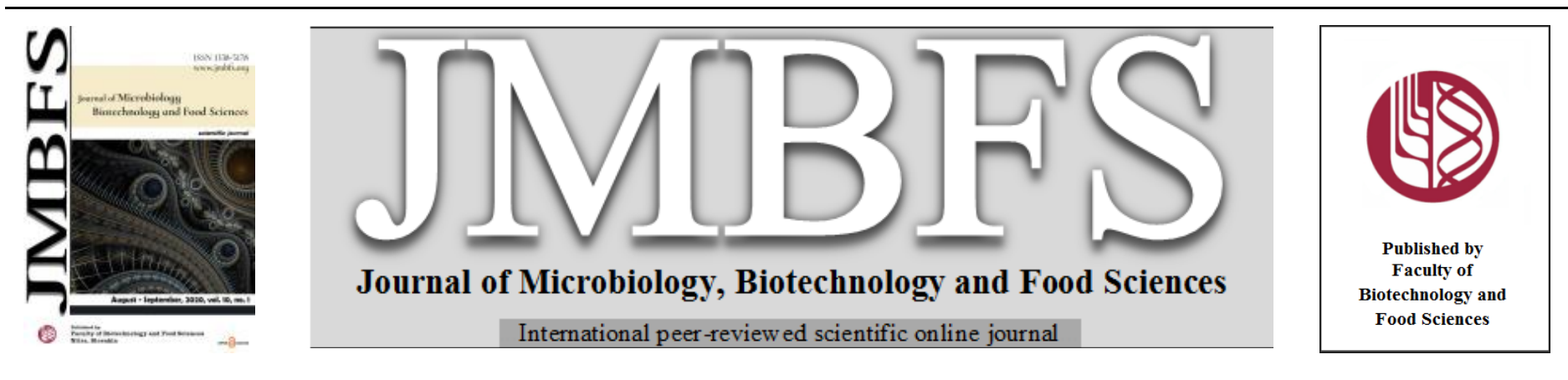

\title{
ANTIBACTERIAL SPECTRUM OF PRODUCED REUTERIN FROM NEW ISOLATES OF Lactobacillus reuteri
}

\author{
Abdulmuttaleb A. Mohammed ${ }^{(1)}$; Nawfal A. Hussain ${ }^{(2)}$; Alaa Kareem Niamah ${ }^{(2) *}$ \\ Address(es): \\ ${ }^{1}$ Fundamental Medical Science Dep., College of Nursing, University of Basrah, 60014, Basrah, Iraq. \\ ${ }^{1}$ Department of Food Science, College of Agriculture, University of Basrah, 60014, Basra, Iraq.
}

*Corresponding author: alaakareem2002@hotmail.com or alaa.niamah@uobasrah.edu.iq

doi: 10.15414/jmbfs.2020.10.1.134-139

\section{ARTICLE INFO}

Received 6.11. 2019

Revised 19. 2. 2020

Accepted 19. 2. 2020

Published 1. 8. 2020

Regular article

OPEN $\partial_{\text {ACCESS }}$

\begin{abstract}
A total number of 20 samples were collected from different local Iraqi sources. The samples were diluted and inoculated on MRS agar medium. After growth, the isolates were transferred on the modified MRS selective agar medium in order to get isolate of Lactobacillus reuteri which able the reuterin production. Five isolates were obtained from the human infant feces (1-3 months), which were tested by morphological, physio-biochemical assays and molecularly confirmed as L. reuteri by detection of the species gene specific. Electrophoresis of PCR products showed bands at the position 303pb while the sequencing and blasting results of these products were revealed $100 \%$ identity of three isolate products to a reference strain L. reuteri ATCC53608 and L. reuteri BPL-36. The fifth residual isolate was limited on physio-biochemical identification as $L$. reuteri due to failing in sequencing.

Infrared spectrum (FT-IR) of extracted reuterin from local isolated was matching with FT-IR of standard reuterin. The antimicrobial inhibitory spectrum of all five isolates was determined against 16 species of gram positive and gram-negative pathogens and food spoilage for their application in food bio-preservation. Escherichia coli and Staphylococcus aureus were observed to be the most affected among the tested organisms, whereas $L$. acidophilus and $L$. plantarum were less affected among them.
\end{abstract}

Keywords: Reuterin, Lactobacillus reuteri, antibacterial activity, FT-IR

\section{INTRODUCTION}

In recent years, many biologists were appeared a wide interest to study antibiotics produced by lactobacilli. This interesting was due to many reasons such as their wide inhibition spectrum for growth of pathogens and food damaging bacteria. In addition, lactobacilli antibiotics represent a natural inhibitors used in food preservation, specially acidic and neutral foods as well as foods needed for heat treatments. The antibiotics and bacteriocins of lactobacilli used commercially as a replacement natural materials against chemical preservatives, which mostly causes a great harms at the level of food safety and human health (Niamah, 2018). This interesting was due to many reasons such as their wide inhibition spectrum for growth of pathogens and food damaging bacteria. In addition, lactobacilli antibiotics represent a natural inhibitors used in food preservation, specially acidic and neutral foods as well as foods needed for heat treatments (Soomro et al., 2002).

One of lactobacilli species is Lactobacillus reuteri, which found naturally in gastrointestinal tract of human, chicken and other animals. L. reuteri can produces of reuterin compound which is an intermediate metabolic compound produce from glycerol fermentation under anaerobic conditions and has a wide inhibition spectrum against other gram positive and gram negative bacteria , molds , yeasts and some proto-organisms (Talapico et al., 1988; Mishra, 2012) . $L$. reuteri is a Gram-positive, non-spore forming, non-motile, facultative anaerobic, rod shaped bacillus, their cells are slightly irregular, bent rods with rounded ends, generally 0.7-1.0 $2.0-3.0 \mu \mathrm{m}$ in size (Kandler and Weiss, 1986), occurring singly, in pairs and in small clusters. The optimum growth temperature is between $37-42{ }^{\circ} \mathrm{C}$ and the optimum growth $\mathrm{pH}$ is about 6.5 (no growth occurs below $\mathrm{pH} 4.5$ ). L. reuteri is an obligate heterofermentetive bacteria can ferment glucose in phosphoketolase metabolic pathway to produces lactate, ethanol, acetic acid and $\mathrm{CO}_{2}$ (Ganzle et al., 2007). L. reuteri is found in types of environmental niches like sour meat, milk, dairy fermentations, and fermented vegetables and in the digestive tract as well as the urogenital tract of humans and warm-blooded animals (Jin et al., 2007; Van Coilie et al., 2007).

Reuterin has a broad spectrum of antimicrobial activity against certain Grampositive and Gram-negative bacteria, yeast, mold and protozoa. The Spoilage organisms also are sensitive to the reuterin such as species of Salmonella, Shigella, Clostridium, Staphylocaccus, Listeria, Candida and Trypanosoma. Reuterin is a hydrosoluble compound, active in a wide range of $\mathrm{pH}$ and has resistance against both of 'proteolytic' and 'lipolytic' enzymes (Da Silva et al.,
2009). The aims of this study is to determine the antibacterial activity of produced reuterin from new isolates of Lactobacillus reuteri.

\section{MATERIAL AND METHODS}

\section{Chemicals}

The essential Chemicals for genetic assays used in this study were agarose, Lysozyme, Master mix (Promega Co. ,USA); Boric acid,Tris-HCl, Tris base, Triton x-100, Ethedium bromide (fisher Co.,USA) ; DNA ladder 100-1500pb Primers (Bioneer Co., Korea) ; EDTA (ethylene diamine tetra acetate),BDH Co.UK; Genomic DNA mini kit, blood /cultured cell (Geneaid Co., Taiwan). Another chemicals and pigments used in the study were Absolute ethanol, Lab M, UK; formalin, BDH, UK; Phosphate buffer saline, Oxoid,UK; Congo red, DAB.6,Germany; Gram's stain, Merck, Germany.

\section{Commercial culture media}

The commercial cultural media used in this study were MRS Agar, MRS broth, Blood agar base(Himedia,India), Simmon citrate agar (Oxoid, England), Nutrient agar (LAB,UK), Nutrient broth (CDH, India), Tryptone soy agar (Alpha, USA), Mueller Hinton agar (DCM, Netherland). All these media were prepared according to their companies and sterilized at $121^{\circ} \mathrm{C}$ for $15 \mathrm{~min}$.

\section{Strains of bacteria test}

The bacterial cultures used in this study are shown in table 1 and used as indicator in the screening of activity and antibacterial spectrum of local L. reuteri isolates.

\section{Culture conditions and assay procedure}

A total number of 20 samples (infant stool and dairy products) were collected as a source of bacterial isolates. The samples were diluted at $0.9 \%$ with sodium phosphate buffer from $10^{-1}$ to $10^{-8}$, then $0.1 \mathrm{ml}$ of each dilution tube were exposed to MRS agar plates by streaking method.

All isolated grown colonies were sub cultured on the selective medium (MRS agar in with $2 \%$ sodium acetate added. The $\mathrm{pH}$ adjusted to 6.2 and sterilized at 
$121^{\circ} \mathrm{C}$ for $15 \mathrm{~min}$. After that, $50 \mathrm{~g} / \mathrm{L}$ of vancomycin was added), and incubated anaerobically at $37^{\circ} \mathrm{C}$ for 48 hour. At the same time, a sterilized mixture of $1 \%$ agar and $2 \%$ glycerol was prepared and stored at $50^{\circ} \mathrm{C}$ in water bath on order.

$\underline{\text { Table } 1 \text { bacterial cultures used in the study }}$

\begin{tabular}{llc}
\hline No. & Bacteria straians & sources \\
\hline $\mathbf{1}$ & E.coli & \\
$\mathbf{2}$ & Staphylococcus aureus & \\
$\mathbf{3}$ & Klebsiella pneumoniae & postgraduate laboratories at the \\
$\mathbf{4}$ & Bacillus subtilis & College of Agriculture, \\
$\mathbf{5}$ & Pseudomonas aeruginosa & University of Basrah \\
$\mathbf{6}$ & Micrococcus sp. & \\
$\mathbf{7}$ & Lactobacillus acidophilus & \\
$\mathbf{8}$ & Lactobacillus plantarum & \\
$\mathbf{9}$ & Staphylococcus epidermidis & AL-Sadr educational hospital at \\
$\mathbf{1 0}$ & Streptococcus. pyogenes & Basrah \\
$\mathbf{1 1}$ & Bacillus sp. & \\
$\mathbf{1 2}$ & Diplococcus sp. & postgraduate laboratories at the \\
$\mathbf{1 3}$ & Klebsiella sp. & College of Science, University of \\
$\mathbf{1 4}$ & Enterococcus sp. & Basrah \\
$\mathbf{1 5}$ & Listeria sp. & Research laboratory at the \\
& & College of nursing, University of \\
$\mathbf{1 6}$ & Clostridium sp. & Basrah \\
& &
\end{tabular}

The agar-glycerol mixture was then poured directly above grown colonies in selective medium and the plates incubated anaerobically at $37^{\circ} \mathrm{C}$ for $1 \mathrm{~h}$. After that, $5 \mathrm{ml}$ of DNPH (2,4-Dinitrophenylhydrazine, Oxoid, England) solution for 3 $\mathrm{min}$. and $5 \mathrm{~mol} / \mathrm{L}$ of potassium hydroxide for $30 \mathrm{sec}$. were added to the medium respectively. The appearance of reddish brown zone around colonies indicate to a positive result (Ortiz-Rivera et al., 2017).

\section{Morphological and biochemical tests}

The morphological characteristics of the colonies were determined on different agar plates as well as the preparation of gram-stained smears from the active cultures, according to standard gram staining procedure, to determine the shape, arrangement and size of individual bacterial cells. Identification of pure colonies was carried out by performing growth at $(10,30,37 \text { and } 42)^{\circ} \mathrm{C}$ for $72 \mathrm{~h}$, growth of $\mathrm{pH}$ values $(4.2,6.2,7.2$ and 9.2), growth in $6.5 \% \mathrm{NaCl}$, growth on Tellurite Agar (TA). Citrate utilization, gelatinase production, catalase production, resistance to $60^{\circ} \mathrm{C}$, motility and resistance to vancomycin. The methods that reported in both of Mishra, 2012; Ariff et al., 2015.

\section{S rRNA of isolates}

PCR method for amplifying the 16S rRNA gene of bacterial isolates was accomplished according to that reported in Garg et al., (2009). The primer used to amplify the specific gene was F-CAGACAATCTTTGATTGTTTAG for forward and R-GCTTGTTGGTTTGGGCTCTTC for reverse. The PCR reaction was carried out in PCR tubes having $25 \mu 1$ reaction mixture including PCR ready to use master mix $(12.5 \mu \mathrm{l})$, template DNA $(5 \mu \mathrm{l})$, forward primer $(1 \mu \mathrm{l})$, reverse primer $(1 \mu \mathrm{l})$ and Nuclease free water $(5.5 \mu \mathrm{l})$. The amplification program involved an initial denaturation at $95^{\circ} \mathrm{C}$ for $10 \mathrm{~min}$, followed by 40 cycles of denaturation at $94^{\circ} \mathrm{C}$ for $15 \mathrm{sec}$, annealing at $60^{\circ} \mathrm{C}$ for $1 \mathrm{~min}$, extension at $72^{\circ} \mathrm{C}$ for $15 \mathrm{sec}$ and followed by a final extension at $72^{\circ} \mathrm{C}$ for $10 \mathrm{~min}$. After detection of PCR product by electrophoresis, the preparation, purification and sequencing of products were done at BIONEER Company, South Korea. All sequencing products were then exposed to treatment and re-correction before they tested in the "BLAST" providing by the National Center for Biotechnology Information Service (NCBI) http://www.ncbi.nlm.nih.gov (Kerbauy et al., 2011)

\section{Production of reuterin supernatant}

Reuterin was produced from $L$. reuteri cultures using methods described elsewhere (Schaefer et al., 2010) with slight modifications. Briefly, overnight grown cultures of $L$. reuteri were inoculated in MRS broth tubes and incubated at $37^{\circ} \mathrm{C}$ for $20 \mathrm{~h}$ in anaerobic conditions. After that, cells from each single broth tube were harvested by centrifugation and washed twice with $50 \mathrm{mM}$ sodium phosphate buffer ( $\mathrm{pH}$ 7.4). The cells were then re-suspended in $15 \mathrm{ml} 250 \mathrm{mM}$ glycerol-water solution and transferred to $15 \mathrm{ml}$ screw-capped tubes with making a solution of water-glycerol without reuterin was used as negative control. The tubes of cell-glycerol suspension were then incubated at $37{ }^{\circ} \mathrm{C}$ for $2 \mathrm{~h}$. in anaerobic conditions. After that, cells were removed from the suspension by centrifugation and filtering the supernatants through $0.22 \mathrm{~mm}$ pore-size filters (Millipore). The resulting cell-free supernatant was then stored in refrigerator at $4^{\circ} \mathrm{C}$ before it analyses by FT-IR test to be contain reuterin and glycerol.

\section{Inhibitory activity spectrum of reuterin}

The activity of reuterin-containing cell-free culture supernatants were determined for their antibacterial inhibitory spectra against a broad range of Gram-positive and Gram-negative indicator strains (table 1). 0.1 milliliter $\left(10^{6} \mathrm{CFU} / \mathrm{ml}\right)$ of 20 hours old cultures of each indicator bacterial cultures was spread on Mullar Hinton agar plates independently, and then 6-millimeter wells were accomplished onto agar plates. The agar wells were then filled with 0.05 milliliter of the reuterin cell-free supernatants and kept undisturbed for 2 hours before the plates were subsequently incubated at $37^{\circ} \mathrm{C}$ for 24 hours. All these experiments for assaying inhibitory activity were performed in triplicate and the zones of growth inhibition around the agar wells were measured by taking the mean of diameters $(\mathrm{mm})$ for each indicator bacterial strains (Niamah,2010).

\section{Statistical analysis}

Statistical analysis of treatments was proceed by using the SPSS Statistics V22.0 (Statistical Package for Social Sciences, USA). Analysis of variance (ANOVA table) of the data was conducted and means for treatments values were analyzed $(\mathrm{P} \leq 0.01)$ with Least Significant Difference (LSD). Differences were considered significant at $\mathrm{P} \leq 0.01$.(Montgomery, 2017).

\section{RESULTS AND DISCUSSION}

In the present study we obtained a results included; the locality isolation of four L. reuteri strains, from human infant stool samples, which identified by morphological, physiochemical and molecular assays; studying the antimicrobial activity of these isolates. A total number of 20 samples were collected from different local sources included of 8 breast fed human infant feces (1-3 months), 3 specimens of human women milk, 3 specimens of white cheese, 3 specimens of yoghurt, and 3 specimens of vinegar.

\section{Cultural morphology and microscopically characters}

All samples plated on MRS agar were resulted to growing of small, cream color, sticky and oval shape colonies. The isolated bacterial cells were found to be short middle in size, purple colored, Gram-positive rods with rounded ends might be found as single cells, pairs or small aggregations under microscope. Hanging drop technique was also performed to test the ability of rod bacterial cells to motile where no motility observed for all five isolates. After transferring of grown colonies from MRS agar and cultivation on selective agar (modified MRS) by stabbing method, the process resulted to obtain of 5 positive grown isolates based on colonial morphology ( brown in color with reddish- brown zone around colonies). Rodriguez et al. (2003) was illustrated that this color is due to the acrolein formed by dehydration of $\beta$-hydroxypropionaldehyde (reuterin), so provides a fast and simple tool for screening of reuterin-producer isolates. The five-reuterin producing colonies, each from a different isolate, were picked up out of agar and selected for further studies (figure 1).

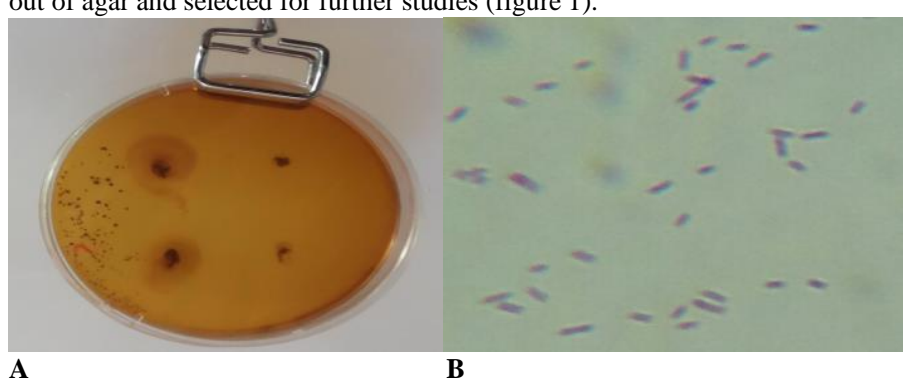

Figure 1 (A) Reddish brown zone around some colonies grown on a selective MRS medium and (B) microscopically features of isolated Lactobacillus bacterial cells.

\section{Physical and biochemical characteristics of isolates}

Table (2) shows the most physical and biochemical characteristics for identification of the five selected isolates to be most likely belonged to the Lactobacillus group, in comparing with previous studies and Bergey's manual of systematic bacteriology (De.Vos and Garrity, 2009).

The five selected bacterial cultures were gave a turbidity after incubation in MRS broth at $(10,30,37 \text { and } 42)^{\circ} \mathrm{C}$ for $72 \mathrm{~h}$. As an indication of microbial growth The best absorbance of growth turbidity was at $37^{\circ} \mathrm{C}$. When the same isolates were incubated at $30^{\circ} \mathrm{C}$ and $42^{\circ} \mathrm{C}$ for $72 \mathrm{~h}$. The absorbance of growth turbidity was at lowest degree than $37^{\circ} \mathrm{C}$; whereas growth at $10^{\circ} \mathrm{C}$ was weaken than other previous test temperatures. These growth results at four different temperatures gave an indicates that the isolates could belong to Lactobacillus group.

The bacterial cultures of selected isolates were also tested for their growth at different $\mathrm{pH}$ levels, where a turbidity appeared after incubation in MRS broth of $\mathrm{pH}(4.2,6.2,7.2$ and 9.2) for $72 \mathrm{~h}$ referring microbial growth. The best absorbance of growth turbidity was at $\mathrm{pH} 6.2$ whereas the absorbance of growth 
turbidity at $\mathrm{pH} 4.2$ was at lowest degree than $\mathrm{pH}$ 6.2. On the other hand, absorbance of growth turbidity at $\mathrm{pH}$ (7.2 and 9.2) was weaken than previous test $\mathrm{pH}$. These growth results at four different $\mathrm{pH}$ gave further indicates that the isolates could belong to Lactobacillus group (Zhoa and Ganzie, 2018). All five selected isolates were appeared the ability of their growth at $6.5 \% \mathrm{NaCl}$ in MRS broth where the absorbance of turbidity referred to a positive results. After incubation at $60^{\circ} \mathrm{C}$ for $30 \mathrm{~min}$, spectrophotometric measurements of MRS broth cultures of all study isolates revealed a very little absorbance, equal to zero, of growth turbidity which indicate that no cells were grown due to heating treatment. This further test gave positive results of study isolates to be belong to
Lactobacillus group where a black colored colonies grown on all Tellurite agar plates isolates after incubation period (Ganzle, 2015; Pallin et al., 2016).

All study isolates were negative results for this test where utilization of citrate was done from these isolates. Inoculated with study isolates, was returned to solidify when it leaved for a period in the laboratory temperature. This referred to a negative result and the isolates were not producing of gelatinase enzyme. Al study isolates were of $\alpha$-hemolysis type depending on green zone that appeared around growing colonies on each TSA plates. The five selected isolates were found to be negative for catalase enzyme production (De.Vos and Garrity, 2009).

Table 2 Physiological and biochemical tests of five selected Lactobacillus isolates

\begin{tabular}{|c|c|c|c|c|c|c|c|c|}
\hline \multirow[b]{2}{*}{ No } & \multirow{2}{*}{\multicolumn{2}{|c|}{ Tests }} & & \multicolumn{5}{|c|}{ Bacterial Isolates } \\
\hline & & & & Isolate 1 & Isolate 2 & Isolate 3 & Isolate 4 & Isolate 5 \\
\hline \multirow{4}{*}{1} & & 10 & & + & + & + & + & + \\
\hline & ${ }^{\circ} \mathrm{C}$ & 30 & & ++ & ++ & ++ & ++ & ++ \\
\hline & & 37 & & +++ & +++ & +++ & +++ & +++ \\
\hline & & 42 & & ++ & ++ & ++ & ++ & ++ \\
\hline \multirow{4}{*}{2} & & & 4.2 & ++ & ++ & ++ & ++ & ++ \\
\hline & $\mathrm{pH}$ & & 6.2 & +++ & +++ & +++ & +++ & +++ \\
\hline & & & 7.2 & + & + & + & + & + \\
\hline & & & 9.2 & + & + & + & + & + \\
\hline 3 & Gro & $\mathrm{h}$ in $6.5 \% \mathrm{NaCl}$ & & ++ & ++ & ++ & ++ & ++ \\
\hline 4 & Res & ance to $60^{\circ} \mathrm{C}$ & & - & & & - & - \\
\hline 5 & Gro & $\mathrm{h}$ on TA medium & & + & + & + & + & + \\
\hline 6 & Citr & utilization & & - & - & - & _ & _ \\
\hline 7 & Gel & nase production & & - & - & - & - & - \\
\hline 8 & Hen & lysis & & $+(\alpha)$ & $+(\alpha)$ & $+(\alpha)$ & $+(\alpha)$ & $+(\alpha)$ \\
\hline 9 & Cat & & & - & - & - & - & - \\
\hline 10 & Mo & & & - & - & - & - & - \\
\hline 11 & Res & ance to vancomycin & & $++\overline{+}$ & $++\overline{+}$ & $+\overline{+}$ & $++\overline{+}$ & $++\overline{+}$ \\
\hline
\end{tabular}

$+++=$ V. good growth, $++=$ good growth, $+=$ weak growth, $-=$ Negative growth, $(+\alpha)=$ positive $($ alfa $)$

\section{S rRNA of Lactobacillus isolates}

The total DNA was used as template for molecular identification of the five isolates. PCR products for the genus specific primer showed bands on agarose gel at the position $303 \mathrm{bp}$ compared with the standard molecular DNA ladder of 100$1000 \mathrm{pb}$ (Figure 2). These results were in agreement with Petrova et al. (2017) who also demonstrated the amplification of 303 bp products in the PCR assay with all isolates of used Lactobacillus reuteri.

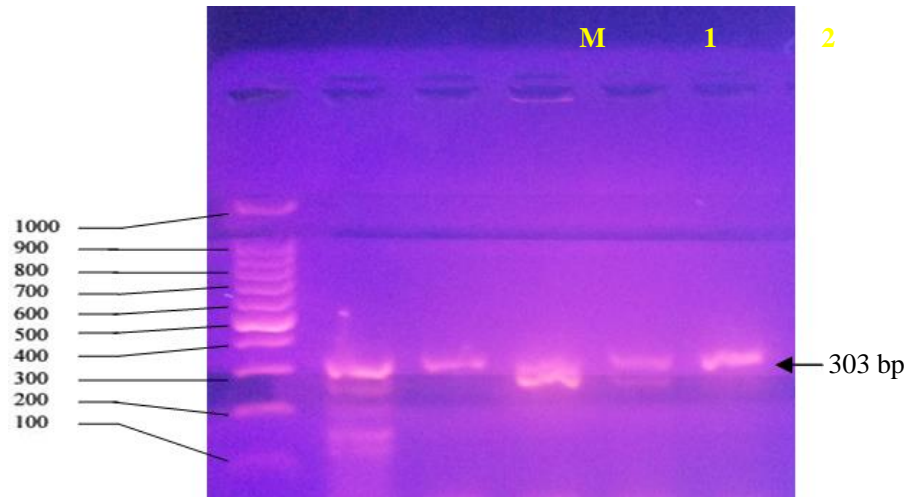

Figure 2 Agarose (2\%) gel electrophoresis of 303 bp specific gene PCR products for L.reuteri isolates under UV transilluminator. Lane (M): $1 \mathrm{~Kb}(100 \mathrm{bp}-1000$ bp) DNA ladder. Lane 1: isolate1. Lane 2: isolate 2 . Lane 3: isolate 3 . Lane 4 isolate 4. Lane 5: isolate 5 .

Table (3) showed out of alignments specific gene sequences for five isolates of $L$. reuteri. Four isolates from infant's stool were identified depending on their specific gene sequencing in comparing with identical reference strains. Three isolates were revealed $100 \%$ identity to a reference strain $L$. reuteri ATCC 53608 and one isolate revealed $100 \%$ identity to a reference strain $L$. reuter BPL36 when treated and tested in European Nucleotide Archive (ENA), National Centre for Biotechnology Information (NCBI) and Gene Bank .

One PCR product from the five that sent to BIONEER Company was failed in sequencing. The peaks of sequence of this product were overlapped with each other so it was difficult to read and treatment. Hence, the identification of this product's isolate was restricted to morphological and biochemical test results. The reason of fail of their sequences may be due to the purification step of PCR product from salts and minerals before sequencing or may be a result to colorization step during sequencing process, where the non-good staining PCR product will causes of interaction between nitrogen bases which be undistinguished by sequencing device leading to obtaining of rubbished sequence. Purification of PCR product was very important to obtain a clear single band in electrophoresis, so the unpurified gene will cause problems during sequencing which lead to difficult reading in Blast program (Ma and Difazio, 2008).

\section{Infrared spectrum of extracted reuterin}

Several distinguished peaks were appeared in the IR absorption spectrum of extracted reuterin compound, table (4) and figure (3). In addition, analysis of these peaks were illustrated their agreement with what reported in Burg'e $\boldsymbol{e t}$ al. (2015). The most important bands were ; the stretch broad band of alcohol hydroxyl $(-\mathrm{OH})$ group at the frequency position $3423 \mathrm{~cm}^{-1}$ and are medium to strong; the stretch band of $(-\mathrm{CH})$ bond at the position $2856 \mathrm{~cm}^{-1}$, which represent Aldehyde group and are weak, sharp. As well as $(\mathrm{C}=\mathrm{O})$ stretch band of aldehyde was distinguished at the frequency $1724 \mathrm{~cm}^{-1}$ which mostly are medium , sharp and saturated. In addition, a stretch band of $(\mathrm{CH})$ bond deal with Alkane was found at $2925 \mathrm{~cm}^{-1}$ were medium to strong, sharp. Moreover, a stretch band of methyl $(-\mathrm{CH})$ bond was appeared at frequency $1406 \mathrm{~cm}^{-1}$ which has variable appearance in the spectrum. The stretch band of $(\mathrm{C}-\mathrm{O})$ appeared in three frequencies represents, alcohol at $1260 \mathrm{~cm}^{-1}$ which was strong and sharp Ether at $1101 \mathrm{~cm}^{-1}$ was strong, and finally, Ester group was appeared at $1026 \mathrm{~cm}^{-1}$ and was medium. The most functional groups that are clearly determine the reuterin compound structure from other near compound are the alcohol hydroxyl group and the aldehyde carbonyl group. The alcohol $\mathrm{OH}$ stretch is broader because single bonds can stretch and bend While the aldehyde $\mathrm{C}=\mathrm{O}$ stretch is sharp and "well-defined because double bonds can stretch, but do not bend very well. 
Table 3 Sequencing results of specific gene and universal 16SrRNA for L. reuteri isolated from local sources.

\begin{tabular}{|c|c|c|c|c|c|c|}
\hline No. & $\begin{array}{l}\text { No. of } \\
\text { isolate }\end{array}$ & $\begin{array}{l}\text { Bacterial } \\
\text { specie }\end{array}$ & Nucleotide sequence & Source & $\begin{array}{l}\text { Identical with } \\
\text { reference strain }\end{array}$ & bp \\
\hline 1 & 3 & L. reuteri & $\begin{array}{l}\text { GCGCATGGTGAATGCCTTGGTACTAGGAG } \\
\text { CCGATGAAGGACGGGACTAACACCGATA } \\
\text { TGCTTCGGGGAGCGGTAAGTACGCTTTGA } \\
\text { TCCGGAGATTTCCGATGGGGCAACCCAA } \\
\text { TCAGCTTAGTCGCTGATTACTTGACTAGT } \\
\text { GAATACATAGCTAGCAAGAGGTAGACGC } \\
\text { AGTGAACTGAAACATCTTAGTAGCTGCAG } \\
\text { GAAGAGAAAGAAACATCGATTCCCTAAG } \\
\text { TAGCGGCGAGCGAAAAGGGAAGAGCCCA } \\
\text { AACCAACAAGCAGGATTTATATTTTTGAT } \\
\text { TGTTTTTTGAATTATTTTGATTTCAATA }\end{array}$ & $\begin{array}{l}\text { infant's } \\
\text { stool }\end{array}$ & $\begin{array}{l}\text { ATCC } \\
100 \%\end{array}$ & 268 \\
\hline 2 & 1 & L. reuteri & $\begin{array}{l}\text { ATGGTGAATGCCTTGGTACTAGGAGCCGA } \\
\text { TGAAGGACGGGACTAACACCGATATGCTT } \\
\text { CGGGGAGCGGTAAGTACGCTTTGATCCGG } \\
\text { AGATTTCCGAATGGGGCAACCCAATCAGC } \\
\text { TTAGTCGCTGATTACTTGACTAGTGAATA } \\
\text { CATAGCTAGCAAGAGGTAGACGCAGTGA } \\
\text { ACTGAAACATCTTAGTAGCTGCAGGAAGA } \\
\text { GAAAGAAACATCGATTCCCTGAGTAGCG } \\
\text { GCGAGCGAAAAGGGAAGAGCCCAAaCCA } \\
\text { ACAAGCATGC }\end{array}$ & $\begin{array}{l}\text { infant's } \\
\text { stool }\end{array}$ & $\begin{array}{l}\text { BPL36 } \\
100 \%\end{array}$ & 264 \\
\hline 3 & 1 & L. reuteri & Failed to sequencing & $\begin{array}{l}\text { infant's } \\
\text { stool }\end{array}$ & - & - \\
\hline
\end{tabular}

Table 4 The bands and their structural groups in the IR spectrum of extracted and standard reuterin.

\begin{tabular}{|c|c|c|c|c|c|}
\hline \multirow{2}{*}{ Functional group } & \multirow{2}{*}{ Bonding } & \multirow{2}{*}{ Vibration type } & \multicolumn{3}{|c|}{ Band frequency $\left(\mathrm{cm}^{-1}\right)$} \\
\hline & & & Band of extracted reuterin & Wavele & range $\left(\mathrm{cm}^{-1}\right)$ \\
\hline Alcohol & $-\mathrm{OH}$ & Stretch. & $3423 \mathrm{~cm}^{-1} \quad$ S.Br. & $3200-3600$ & \\
\hline Aldehyde & $-\mathrm{CH}$ & Stretch. & $2856 \mathrm{~cm}^{-1} \mathrm{~W}$ & $2850-3000$ & \\
\hline Alkanes & $-\mathrm{CH}$ & Stretch. & $2925 \mathrm{~cm}^{-1} \mathrm{M}$ & $2878-2990$ & \\
\hline Aldehyde & $\mathrm{C}=\mathrm{O}$ & Stretch. & $1724 \mathrm{~cm}^{-1} \mathrm{~S}$. & $1720-1740$ & \\
\hline $\mathrm{CH}$ of $\mathrm{CH}_{3}$ & $-\mathrm{CH}$ & Stretch. & $1406 \mathrm{~cm}^{-1} \mathrm{~V}$ & $1350-1480$ & \\
\hline Alcohol & $\mathrm{C}-\mathrm{O}$ & Stretch. & $1260 \mathrm{~cm}^{-1} \mathrm{~S}$. & & $1000-1300$ \\
\hline Ether & $\mathrm{C}-\mathrm{O}$ & Stretch. & $1101 \mathrm{~cm}^{-1} \mathrm{~S}$. & & $1031-1118$ \\
\hline Ester & $\mathrm{C}-\mathrm{O}$ & Stretch. & $1026 \mathrm{~cm}^{-1} \mathrm{M}$. & & $1000-1300$ \\
\hline
\end{tabular}

* $\mathrm{Br}$ = broad; $\mathrm{W}=$ weak; $\mathrm{M}=$ medium; $\mathrm{S}=$ strong; $\mathrm{V}$ = variable

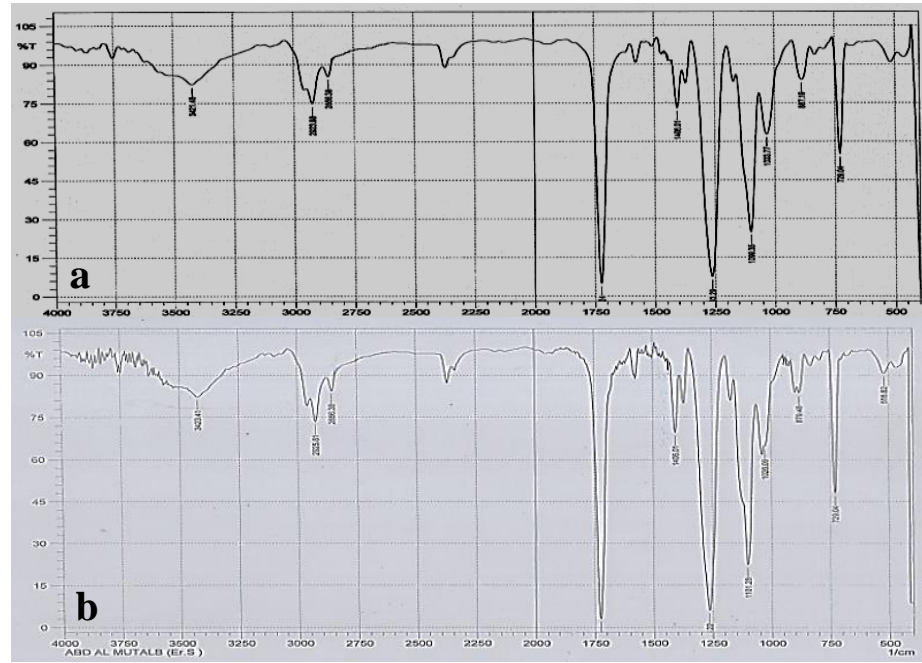

Figure 3 IR absorption spectrum of extracted and standard reuterin. a. Standard reuterin, b. extracted reuterin produced from local isolates.

\section{Antibacterial activity spectrum of $L$. reuteri isolates}

Table (5) and figure (4) show the inhibition effect of the culture supernatant, of the five $L$. reuteri isolates, against a wide range of Gram positive and Gram negative indicator bacterial isolates. The test was included $L$. reuteri itself and two bacterial species that classically related to it, as well as, 16 species of food spoilage and food borne pathogen as indicator bacteria. The spectrum was showed a weak inhibition zones $(<10 \mathrm{~mm})$ to strong inhibition zones $(>20 \mathrm{~mm})$ while the range in between was divided to intermediate inhibition zones ( from $10 \mathrm{~mm}$ up to $15 \mathrm{~mm}$ ) and less strong inhibition zones (from $16 \mathrm{~mm}$ up to $20 \mathrm{~mm}$ ). On the other hand, no sensitivity shown when we subjected the five L. reuteri isolates to the culture supernatants of each to other. Therefore, this refer to reuterin has no effect on the producer $L$. reuteri itself. Our results were agreement with many other studies, which indicated the antibacterial ability of reuterin. Mishra ( 2012) was stated L. reuteri as all other lactic acid bacteria has been reported to produce various organic acids during fermentation, such as lactic acid and acetic acid, which lead to lowering of $\mathrm{pH}$ in the gastrointestinal tract. The organic acids besides the production of reuterin gave $L$. reuteri a strong antagonistic effect, where they served as potent antibacterial agents against pathogenic bacteria (Cleusix et al., 2007). The antagonistic effect of L. reuteri as well as their ability to survive at lower $\mathrm{pH}$ were considered beneficial in maintaining general health of the gastrointestinal tract and female genital tract of the host. The reuterin produced from L. reuteri DPC16 (Human source) had potent antibacterial activity against both Gram positive and Gram negative pathogenic bacteria such as S. typhimurium, E. coli 157:H7, S. aureus and L. monocytogenes ( Bian et al., 2011). The supernatant of 14 L. reuteri (Iranian source) had antimicrobial activity against two indicator bacteria (Salmonella enteritidis and S. typhimurium) ( Royan et al., 2018) . Reuterin is a mixture of three dimeric forms of the 3-hdroxypropionaldehyde (3-HPA) compound. This compound can be transformed in aqueous solution to the compound acrolein , which has been considered as a toxic material and is able to reacts with other compounds that present in the food products. The mechanism of action of reuterin compound, spends its antimicrobial effects, has stay elusive. In study, we supply evidence that reuterin induces oxidative stress in microorganism cells, most probable by changing thiol groups in protein compounds and other small molecules in the cells. The action mode of reuterin's antimicrobial activity has been suggested to be an imbalance in cellular redox state produced from reaction of 3-hdroxypropionaldehyde with thiol groups of proteins, rising the reduction of glutathione and changes in proteins complex in clusiving functional enzymes. In addition to its well investigated inhibition activities, reuterin compound is 
involved in the conjunction of heterocyclic amines, apparition of possible contacts to the bioavailability of toxicant compound against microorganisms in the human intestine (Engels $\boldsymbol{e t}$ al., 2016). The supernatants exhibited a broad spectrum of inhibitory action against aerobic and anaerobic spore-forming bacteria (González et al., 2019).

\begin{tabular}{|c|c|c|c|c|c|c|}
\hline No. & Strains test & LR1 & LR2 & LR3 & LR4 & LR5 \\
\hline 1 & E.coli & ++++ & ++++ & ++++ & ++++ & ++++ \\
\hline 2 & $\begin{array}{l}\text { Staphylococcus } \\
\text { aureus }\end{array}$ & ++++ & +++ & +++ & ++++ & ++++ \\
\hline 3 & $\begin{array}{l}\text { Klebsiella } \\
\text { pneumoniae }\end{array}$ & ++ & ++ & ++ & ++ & ++ \\
\hline 4 & Bacillus subtilis & +++ & +++ & +++ & +++ & +++ \\
\hline 5 & $\begin{array}{l}\text { Pseudomonas } \\
\text { aeruginosa }\end{array}$ & +++ & +++ & +++ & +++ & +++ \\
\hline 6 & Micrococcus sp. & ++ & ++ & ++ & ++ & ++ \\
\hline 7 & $\begin{array}{l}\text { Lactobacillus } \\
\text { acidophilus }\end{array}$ & +++ & ++ & ++ & ++ & ++ \\
\hline 8 & $\begin{array}{l}\text { Lactobacillus } \\
\text { plantarum }\end{array}$ & +++ & ++ & ++ & ++ & ++ \\
\hline 9 & $\begin{array}{l}\text { Staphylococcus } \\
\text { epidermidis }\end{array}$ & +++ & +++ & +++ & +++ & +++ \\
\hline 10 & $\begin{array}{l}\text { Streptococcus. } \\
\text { pyogenes }\end{array}$ & ++ & ++ & ++ & ++ & ++ \\
\hline 11 & Bacillus sp. & + & + & + & + & + \\
\hline 12 & Diplococcus sp. & + & + & + & + & + \\
\hline 13 & Klebsiella sp. & ++ & ++ & ++ & ++ & ++ \\
\hline 14 & Enterococcus sp. & ++ & ++ & ++ & ++ & ++ \\
\hline 15 & Listeria $\mathrm{sp}$. & ++ & ++ & ++ & +++ & ++ \\
\hline 16 & Clostridium sp. & ++ & ++ & ++ & ++ & ++ \\
\hline
\end{tabular}

- = no inhibition; $+<10 \mathrm{~mm} ;++=10-15 \mathrm{~mm} ;+++=16-20 \mathrm{~mm} ;++++$ $>20 \mathrm{~mm}$

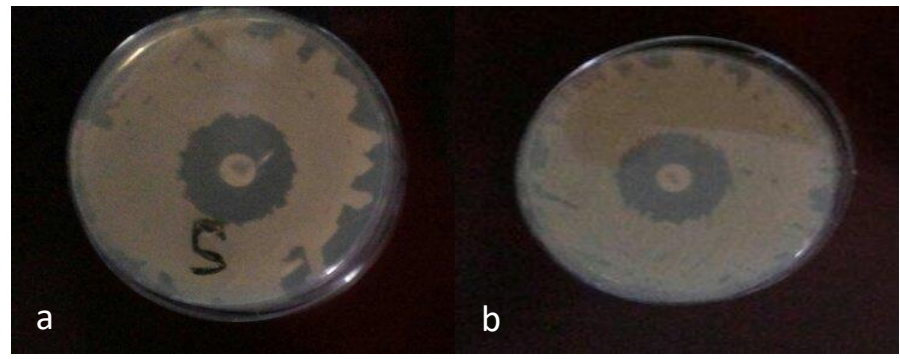

Figure 4 Antibacterial activity of isolates against test bacteria, a. gram positive $S$ aureus b. gram negative E. coli.

\section{CONCLUSION}

Lactobacillus reuteri strains are among the primary microbiological barriers in human body against the infection by intestinal pathogens. They were isolated from infant feces. 16S rRNA test shows to match between local isolates and strains L. reuteri ATCC53608 and L. reuteri BPL-36. They have a strong potential to produce of inhibitory substance, such as reuterin, which have a wide antimicrobial spectrum including those have near genetic relationship. The produced reuterin from local isolates had higher inhibition spectrum against 16 types of bacteria strains.

Acknowledgments: The author wishes to thank all persons and institutes who support of this research. Also thanks the valuable help of Khloud A.H., the instructor in Nursing College, Basra University for assistance received in Genetic tests.

\section{REFERENCES}

Al-KHAFAGI, Z. M., Al-KHATAUA, K. J., RASHEED, M. N., GHREEB, A M. 2014. Credibility of its primers in identification of Lactobacillus species of Iraqi virginal microbiome. world J. of Pharmacy and Pharmaceutical Sciences, 3,93-106.

ARIEF, I. I., JENIE, B. S. L., ASTAWAN, M., FUJIYAMA, K., WITARTO, A B. 2015. Identification and probiotic characteristics of lactic acid bacteria isolated from Indonesian local beef. Asian J. Anim. Sci, 9, 25-36. https://doi.org/10.3923/ajas.2015.25.36.

CADIEUX, P., WIND, A., SOMMER, P., SCHAEFER, L., CROWLEY, K. BRITTON, R. A., REID, G. 2008. Evaluation of reuterin production in urogenita probiotic Lactobacillus reuteri RC-14. Appl. Environ. Microbiol, 74, 4645-4649. https://doi.org/10.1128/AEM.00139-08.

CLEUSIX, V., LACROIX, C., VOLLENWEIDER, S., DUBOUX M., Le BLAY, G.2007. Inhibitory activity spectrum of reuterin produced by Lactobacillus reuteri against intestinal bacteria. BMC microbiology, 7 , https://doi.org/10.1186/1471-2180-7-101.

De Vos, P., \& Garrity, G. M.. Bergey's manual of systematic bacteriology. Springer. (2009).

El ABDOUNI KHAYARI, M., JAMALI, C. A., KASRATI, A., HASSANI, L. LEACH, D., MARKOUK, M., ABBAD, A. 2016. Antibacterial activity of essential oils of some moroccan aromatic herbs against selected food-related bacteria. Journal of Essential Oil Bearing Plants, 19, 1075-1085. https://doi.org/10.1080/0972060X.2015.1004123.

FREEMAN, D. J., FALKINER, F. R., KEANE, C. T. 1989. New method for detecting slime production by coagulase negative staphylococci. Journal of clinical pathology, 42, 872-874. https://doi.org/10.1136/jcp.42.8.872.

GAENZLE, M. G. 2015. Lactic metabolism revisited metabolism of lactic acid bacteria in food fermentations and food spoilage. Current Opinion in Food Science, 2,106-117. https://doi.org/10.1016/j.cofs.2015.03.001.

GARG, K. B., GANGULI, I., DAS, R., TALWAR, G. P. 2009. Spectrum of Lactobacillus species present in healthy vagina of Indian women. Indian Journal of Medical Research, 129, 652.

GANZLE, M. G., VERMEULEN, N., VOGEL, R. F. 2007. Carbohydrate, peptide and lipid metabolism of lactic acid bacteria in sourdough. Food microbiology, 24,128-138. https://doi.org/10.1016/j.fm.2006.07.006.

GONZÁlEZ, M.J., OLIVERA, J., CHILIBROSTE, P., REGINENSI, S. 2019. Bioconversion of crude glycerol into reuterin by lactobacilli isolated from silage.Journal of Microbiology, Biotechnology and Food Sciences, 9, 174-178 https://doi.org/10.15414/jmbfs.2019.9.2.174-178.

HOU, C., ZENG, X., YANG, F., LIU, H., QIAO, S. 2015. Study and use of the probiotic Lactobacillus reuteri in pigs: a review. Journal of animal science and biotechnology, 6, 14. https://doi.org/10.1186/s40104-015-0014-3.

JIN, L., TAO, L., PAVLOVA, S. I., SO, J. S., KIWANUKA, N., NAMUKWAYA, Z., SABERBEIN, B.A., WAWER, M. 2007. Species diversity and relative abundance of vaginal lactic acid bacteria from women in Uganda and Korea. Journal of applied microbiology, 102, 1107-1115. https://doi.org/10.1111/j.1365-2672.2006.03147.x.

JONES, S. E., VERSALOVIC, J. 2009. Probiotic Lactobacillus reuteri biofilms produce antimicrobial and anti-inflammatory factors. BMC microbiology, 9, 35 https://doi.org/10.1186/1471-2180-9-35.

KAWAI, Y., ISHII, Y., ARAKAWA, K., UEMURA, K., SAITOH, B. NISHIMURA, J., KITAZAWA, H., YAMAZAKI, Y., TATENO, Y., ITOH, T., SAITO, T. 2004. Structural and functional differences in two cyclic bacteriocins with the same sequences produced by lactobacilli. Appl. Environ. Microbiol, 70 2906-2911. https://doi.org/10.1128/aem.70.5.2906-2911.2004.

KERBAUY, G., PERUGINI, M. R. E., YAMAUCHI, L. M., YAMADAOGATTA, S. F. 2011. Vancomycin-dependent Enterococcus faecium van A characterization of the first case isolated in a university hospital in Brazil. Brazilian Journal of Medical and Biological Research, 44, 253-257. http://dx.doi.org/10.1590/S0100-879X2011007500006.

MA, H., DIFAZIO, S. 2008. An efficient method for purification of PCR products for sequencing. Biotechniques, 44, 921-923. http://dx.doi.org/10.2144/000112809.

MISHRA, S. K., MALIK, R. K., MANJU, G., PANDEY, N., SINGROHA, G. BEHARE, P., KAUSHIK, J. K. 2012. Characterization of a reuterin-producing Lactobacillus reuteri BPL-36 strain isolated from human infant fecal sample. Probiotics and antimicrobial proteins, 4, 154-161. http://dx.doi.org/10.1007/s12602-012-9103-1.

MIYOSHI, T., IWATSUKI, T., NAGANUMA, T. 2005. Phylogenetic characterization of $16 \mathrm{~S}$ rRNA gene clones from deep-groundwater microorganisms that pass through 0.2 -micrometer-pore-size filters. Appl. Environ. Microbiol, 71, 1084-1088. http://dx.doi.org/10.1128/AEM.71.2.10841088.2005.

NIAMAH, A. K. 2010. Production of pediocin like bacteriocin from a local isolate of Pediococcus acidilactici and using it as foods preservative. $\mathrm{Ph}$. D. Thesis, Coll. Agriculture, Univ. Basrah, 177pp. http://dx.doi.org/10.13140/RG.2.2.31314.35529.

NIAMAH, A. K. 2018. Structure, mode of action and application of pediocin natural antimicrobial food preservative: A review. Basrah Journal of Agricultural Sciences, 31(1), 59-69. https://doi.org/10.37077/25200860.2018.76.

ORTIZ-RIVERA，Y., SANCHEZ-VEGA， R., GUTIERREZ-MENDEZ，N., LEON-FELIX, J., ACOSTA-MUNIZ, C., SEPULVEDA, D. R. 2017 Production of reuterin in a fermented milk product by Lactobacillus reuteri Inhibition of pathogens, spoilage microorganisms, and lactic acid bacteria. Journal of dairy science, 100, 4258-4268. http://dx.doi.org/10.3168/jds.2016-11534.

PALLIN, A., AGBACK, P., JONSSON, H., ROOS, S. 2016. Evaluation of growth, metabolism and production of potentially bioactive components during fermentation of barley with Lactobacillus reuteri. Food microbiology, 57, 159171. http://dx.doi.org/10.1016/j.fm.2016.02.011.

PETROVA, M. I., REID, G., VANEECHOUTTE, M., LEBEER, S. 2017. Lactobacillus iners: friend or foe? Trends in microbiology, 25, 182-191. http://dx.doi.org/10.1016/j.tim.2016.11.007. 
RODRIGUEZ, E., ARQUES, J. L., RODRIGUEZ, R., NUNEZ, M., MEDINA, M. 2003. Reuterin production by lactobacilli isolated from pig faces and evaluation of probiotic traits. Letters in applied microbiology, 37, 259-263. http://dx.doi.org/10.1046/j.1472-765x.2003.01390.x.

SAMBROOK, J., RUSSELL, D.W. 2001. Molecular Cloning-A Laboratory Manual, $3^{\text {rd }}$ edition. Cold Spring Harbor Laboratory Press, Cold Spring Harbor, NY, USA, P.300-360

SCHAEFER, L., AUCHTUNG, T. A., HERMANS, K. E., WHITEHEAD, D., BORHAN, B., BRITTON, R. A. 2010. The antimicrobial compound reuterin (3hydroxy propionaldehyde) induces oxidative stress via interaction with thiol groups. Microbiology, 156, 1589-1599. http://dx.doi.org/10.1099/mic.0.035642

SLIZOVA, M., NEMCOVA, R., MADAR, M., HADRYOVA, J, GANCARCIKOVA, S., POPPER, M., PISTL, J. 2015. Analysis of biofilm formation by intestinal lactobacilli. Canadian journal of microbiology, 61, 437446. http://dx.doi.org/10.1139/cjm-2015-0007.

SOOMRO, A. H., MASUD, T. ANWAAR, K. 2002. Role of lactic acid bacteria (LAB) in food preservation and human health-a review. Pakistan Journal of Nutrition, 1(1), 20-24. https://doi.org/10.3923/pjn.2002.20.24.

STILES, M. E., HOLZAPFEL, W. H.1997. Lactic acid bacteria of foods and their current taxonomy. International journal of food microbiology, 36, 1-29. http://dx.doi.org/10.1016/s0168-1605(96)01233-0.

TALARICO, T. L., DOBROGOSZ, W. J. 1989. Chemical characterization of an antimicrobial substance produced by Lactobacillus reuteri. Antimicrobial agents and chemotherapy, 33, 674-679. https://doi.org/10.1128/aac.33.5.674.

VAN COILLIE, E., GORIS, J., CLEENWERCK, I., GRIJSPEERDT, K., BOTTELDOORN, N., VAN IMMERSEEL, F., DE BUCK, J., VANCANNEYT, M., SWINGS, J., HERMAN, L., HEYNDRICKX, M. 2012. Identification of lactobacilli isolated from the cloaca and vagina of laying hens and characterization for potential use as probiotics to control Salmonella enteritidis. Journal of Applied Microbiology, 102, 1095-1106. https://doi.org/10.1111/j.1365-2672.2006.03164.x.

VOLLENWEIDER, S., GRASSI, G., KONIG, I., PUHAN, Z. 2003. Purification and structural characterization of 3-hydroxypropionaldehyde and its derivatives. Journal of agricultural and food chemistry, 51, 3287-3293. https://doi.org/10.1021/jf021086d.

ZHAO, X., GANZLE, M. G. 2018. Genetic and phenotypic analysis of carbohydrate metabolism and transport in Lactobacillus reuteri. International journal of food microbiology, 272, $12-21$. https://doi.org/10.1016/j.ijfoodmicro.2018.02.021. 